\title{
SOURCE-IN-TARGET METONYMY AND TARGET-IN-SOURCE METONYMY IN TEXTS ON INTERNATIONAL AFFAIRS
}

\author{
Aleksandra Aleksandrova ${ }^{1}$
}

\begin{abstract}
The paper deals with the way source-in-target metonymy and target-insource metonymy are used in text on international affairs. In such texts, the notion in the source domain is typically a toponym, but there are cases in which the source can be an ethnonym derived from a toponym. With target-in-source metonymies, the source domain stands for a target sub-domain. With source-in-target metonymies, a source sub-domain stands for a target domain. Both types of metonymy are unidirectional, as the target concept activated by the source concept does not in its turn activate the source concept in the same text. The study traces the way those types of metonymy are exploited in the media and studies the similarities and differences in their use in Bulgarian and English language texts.
\end{abstract}

Key words: source-in-target metonymy, target-in-source metonymy, media texts, place names

\section{Introduction}

The paper deals with the way source-in-target metonymy and target-in-source metonymy are exploited in media texts discussing foreign affairs. It traces the main types of source-in-target metonymy and target-in-source metonymy used in such texts and the characteristic features of their use.

Ruiz de Mendoza Ibáñez and Pérez Hernández (2001) divide metonymies into two types: target-in-source metonymy and source-in-target metonymy. With targetin-source metonymies, the source domain stands for a target sub-domain. With source-in-target metonymies, a source sub-domain stands for a target domain. An example of a target-in-source metonymy is Wall Street is in crisis, while The ham sandwich is waiting for his bill is a source-in-target metonymy. According to Croft, domains play a significant role in most metonymies (Croft, 2002). As stated by Mendoza Ibáñez, in their interaction with metaphor, source-in-target metonymies signal the central inference of the metaphoric mapping, while target-in-source metonymies highlight some aspects of the target. According to Castillo, source-in target metonymies are processes of domain expansion, while target-in-source metonymies are processes of domain reduction (Castillo,

1. Assistant Prof. at Shumen University, Department of English Studies, Shumen, Bulgaria, e-mail: a.aleksandrova@shu.bg 
2004). As stated by Mendoza Ibáñez and Velasco, source-in-target metonymies need "either the context or the semantic domain typically associated with the expression to trigger the metonymic shift, while target-in-source metonymies need the predicate" (Velasco, 2002, p.489). In Barcelona's view, metonymies are reversible, but unidirectional (Barcelona, 2011). This means that the source and the target do not simultaneously map onto each other (ibid.). There is also a case for saying that certain deviations in implied meanings are observed with regard to source and target language comparative analysis (Peneva, 2019).

\section{Analysis}

Well-exploited metonymies in media are the continent or the geographical region for a country situated on that continent/ region, and the continent for a group of countries situated on that continent. A widely-spread is the use of America for the United States of America:

\section{One of America's most able diplomats - and his demons}

Kurt Campbell on why Richard Holbrooke, architect of the Dayton peace accord, was haunted by Vietnam

The $\boldsymbol{U} \boldsymbol{S}$ Department of State is an unsentimental institution. Generations of American diplomats have laboured there, negotiating treaties, engaging enemies and friends alike, and advancing the national interest overseas. The top two floors of its headquarters in Foggy Bottom, one of Washington's oldest neighbourhoods, are ostentatiously ornate, with colonial-era furniture and gold-framed portraits adorning the walls of former secretaries and diplomatic emissaries such as Benjamin Franklin (FT/ 05.03.2019).

In the above excerpt, America is used to stand for the USA. This is not exactly an example of a geographical region for the country, nor is it a metonymy of the type the continent for the country, since there is not a continent called America. The proprial lexeme America is part of the continents names South America and North America, but standing by itself it does not refer to any of the two. In any case, both South America and North America are home to other countries apart from the US, which is only one of the countries, situated in North America.

In the above example, America and the US are used interchangeably and are contextually synonymous:

America $=$ US

The source America activates the target US:

America $\Rightarrow$ US

However, the opposite direction is not valid - the target $U S$ does not activate the source America in the above text. 


\section{$U S \Rightarrow$ Ameriea}

The metonymy is unidirectional.

Another well exploited metonymy in media texts, especially in those related to international affairs is the continent for an organization of countries, situated on the continent. The toponym Europe is typically used to refer to the European Union, as illustrated in the following excerpt:

\section{Europe must rethink fiscal rules to combat populism}

Tight spending policy and stagnant incomes have stoked political anger The campaign for the UK to remain in the $\boldsymbol{E} \boldsymbol{U}$ lost for many reasons, none more important than a general failure to understand the multiple anxieties of lower to middle-income voters. This shortcoming is not unique to the UK. It is a broad phenomenon of late-cycle liberal capitalism. The situation in the $\boldsymbol{E} \boldsymbol{U}$ ahead of the European parliamentary elections between May 23 and 26 is not quite as binary as it was in the UK three years ago. The insurrection against pro-European liberalism is proceeding in smaller steps. (FT/ 12.08.2019)

This type of metonymy is so well established that the derivative words formed from Europe, such as the ethnonym European are also used metonymically.

\begin{tabular}{|l|l|}
\hline Source & Target \\
\hline Europe & The European Union \\
\hline $\begin{array}{l}\text { European (parliamentary) } \\
\text { elections }\end{array}$ & Elections for members of the parliament of the European Union \\
\hline Pro-European & Supporting the idea of the EU \\
\hline
\end{tabular}

The source is a notion from the domain of geography and it activates the targeta notion from the domain of (international) politics. This type of metonymy can be regarded as a whole-for-the part metonymy, as the target, the EU does not include all the countries on the territory of Europe. As in the previous excerpt, the metonymy is uni-directional, as it does not function in the opposite direction ( $E U$ does not activate Europe in that text).

While the above texts illustrate the use of target in source metonymies, the next text demonstrate the use of both target in source and source in target metonymy:

\section{Russia divides Europe's eurosceptic parties}

Divisions on how to handle Russia's "neo-imperial appetite", among other factors, are set to block Italian far-right deputy prime minister Matteo Salvini's ambitions 
to spearhead a new European Parliament (EP) league, Jan Zahradil, a leading Czech MEP and candidate for European Commission president has said.

Britain's departure from the $\boldsymbol{E} \boldsymbol{U}$ will also shift the balance of power toward the more Russia-friendly France and Germany, stoking tension with central European and Baltic countries, the Czech politician told EUobserver in an interview (EUobserver/ 12.08.2019)

Europe for the European Union is an example of target-in-source metonymy. Britain standing for the UK, however, is a source-in-target metonymy. Both metonymies are unidirectional, since in the above text neither EU automatically invokes Europe, nor does UK necessarily stand for Britain.

In the following article, Britain stands for the UK, forming source-intarget metonymy. The ethnonym derived from Britain, British, is also used metonymically. 'British identity' in the text below stands for identity of the people, living in the UK.

\section{Leavers v remainers: how Britain's tribes compare}

Survey reveals surprising consensus - but big divisions exist over identity, culture and gender

Whatever happens with Brexit, the EU referendum has spawned two political tribes. The identities "leaver" and "remainer" cut across traditional party divides: research suggests they are replacing Conservative, Labour and Liberal Democrat as indicators of political identity. But how much do they really differ?

Graphs plotting the distributions of their answers to a range of questions often show a bell curve in which both sides mostly overlap, even on divisive issues such as immigration. It seems the starkest differences relate to British identity itself - with a notable divergence on gender politics $(\mathrm{G} / 02.05 .2019)$

It could also be suggested that the already well established neologism Brexit is constructed on the basis of source-in-target metonymy, since the referendum was whether the whole UK, not only Britain, to leave the EU.

The target $U K$ is often activated by the toponym England in the source domain, as is the case in the following excerpt:

\section{England and France: a tale of two coastlines}

On the eve of D-day's 75th anniversary, with Brexit looming, how do those on either side of the Channel feel?

The landscape remains as it was then," says Mark Worthington, waving across marshland and poplar trees laden with mistletoe. He stands beside Pegasus Bridge, across the Caen Canal at Ranville, Normandy, taken on 5 
June 1944 by an allied advance party that arrived to clear the way for D-day, and the liberation of western Europe.

Worthington, curator of the Pegasus Bridge commemorative museum on this site, proceeds to the cemetery of British soldiers killed on, or soon after, D-day - rows and rows of lost lives. In the graveyard of the lovely church next door "are German graves, and that of the first man to die at D-day, on Pegasus Bridge, Pte Den Brotheridge" - of whom a statue was unveiled in Portsmouth during the week of our visit to Ranville, where it later went for display (G/ 12.08.2019)

From geographical point of view, England is a part of Great Britain, which in turn is a part of the United Kingdom of Great Britain and Northern Ireland. However, the three notions do not create a metonymic tier of the type England $\rightarrow$ Britain $\rightarrow$ United Kingdom. Instead, England refers directly to the United Kingdom. Schematically, it can be presented in the following way:

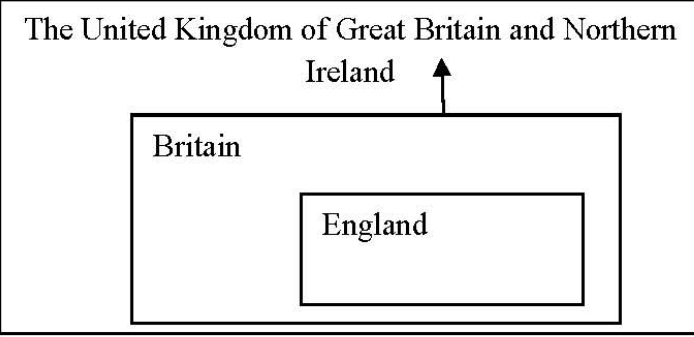

In the next excerpt, Eвpona referring to the EU is an example of target-insource metonymy:

\section{Нови цени за роуминг в Eвропа}

Цената на минута разговор с ДДС не трябва да е над 45 ст., а на СМС 14 ст., доставчиците трябва да съобщят за промените

От 15 май започва да се прилага регулация на цените на международните повиквания и на кратките текстови съобщения в рамките на $\boldsymbol{E C}$. След тази дата цените на дребно за мобилни и фиксирани повиквания от една до друга държава в $\boldsymbol{E} \boldsymbol{C}$ не трябва да превишават 19 евроцента на минута. Ценовият таван за кратко текстово съобщение в рамките на Съюза ще бъде 6 евроцента за съобщение, съобщават от Комисията за регулиране на съобщенията (Vesti/ 12.08.2019)

\section{New roaming charges in Europe}

The price for a minute phone call should not exceed 45 stotinki with VAT, and an SMS should not exceed 14 stotinki. The providers should inform about the changes. 
A regulation of international calls and SMS charges within the $\boldsymbol{E} \boldsymbol{U}$ will be applied from May $15^{\text {th }}$. After that date the retail roaming charges for mobile or fixed phone calls between countries in the $\boldsymbol{E} \boldsymbol{U}$ should not exceed 19 eurocent per minute. The price ceiling for an SMS in the Union will be 6 eurocent per message, as stated by the Commission for communications regulation. ${ }^{2}$

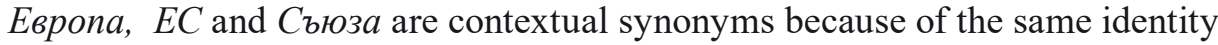
of the named object (Todorova, 2012), but it is only Eвpona that activates the target $\mathrm{ECl}$ Съюз $\mathrm{a}$ and not vice versa.

A target-in-source metonymy is also observed in use of ethnonyms. In the next excerpt, the ethnonym американците refers to the US citizens, just as the toponym America was used to stand for the USA in one of the above excerpts from the Financial Times:

Американците не харесват външната политика на Тръмп

Те не смятат, че международната позиция на САЩ се подобрява

Мнозинството от американци не харесват начина, по който президентът Доналд Тръмп води външната политика на САЩ (Fakti/ 28.01.2019)

The Americans do not like Trump's international policy

They do not believe that the US international position improves.

The majority of Americans do not like the way President Donald Trump leads $\boldsymbol{U} \boldsymbol{S}$ international policy.

In the next excerpt, the toponym Англия referring to the United Kingdom is a source-in-target metonymy:

\section{Българин изчезна в Англия, разследват убийство}

Българският гражданин на възраст 27 години е бил видял за последно в търговския център в Есекс

Двадесет и две годишен мъж е арестуван в хода на разследване за изчезнал във Великобритания български гражданин (Vesti/ 02.05.2019)

A Bulgarian disappeared in England, a murder investigation is carried out The 27 year old Bulgarian citizen has been last seen in a shopping centre in Essex

2.Translations of the articles in Bulgarian provided by the author. 
A 22 year old man was arrested during an investigation on a Bulgarian citizen who disappeared in Great Britain.

Великобритания (Great Britain) used to stand for the United Kingdom is also an example of source-in-target metonymy.

Великобритания (Great Britain)

У

United Kingdom

Англия (England) $\pi$

\section{Conclusion}

The use of source-in-target and target-in-source metonymy is widely exploited in both Bulgarian and English-language media text dealing with international affairs. In such texts, the notion in the source domain is typically a toponym, but there are cases in which the source can be an ethnonym derived from a toponym. Both source-in-target and target-in-source metonymy are unidirectional, as the target concept activated by the source concept does not in its turn activate the source concept in the same text.

\section{References}

[Interview] Russia divides Europe's eurosceptic parties. (n.d.). Retrieved from https:// euobserver.com/foreign/144631

Barcelona, A. (2011). Reviewing the properties and prototype structure of metonymy. In R. Réka Benczes, A. Barcelona, F. J. Ruiz de Mendoza Ibáñez (Eds.) Defining metonymy in cognitive linguistics. Towards a consensus view (pp. 7-60). John Benjamins. Publishing Company.

Campbell, K. (2019, May 03). One of America's most able diplomats - and his demons. Retrieved from https://www.ft.com/content/85c9b59e-6a70-11e9-9ff9-8c855179f1c4

Castillo, J. F. G. (2004). Jornades de Foment de la Investigació - Repositori UJI. Retrieved from http://repositori.uji.es/xmlui/bitstream/handle/10234/78888/forum_2004_3. pdf? sequence $=1$

Clarke, S., Kommenda, N., \& Lewis, P. (n.d.). Leavers v remainers: How Britain's tribes compare. Retrieved from https://www.theguardian.com/world/ng-interactive/2019/ may/02/leavers-v-remainers-how-britains-tribes-compare

Croft, W. (2002). The role of domains in the interpretation of metaphors and metonymies. In R. Dirven, R. W. Langacker, \& J. R. Taylor (Eds). Metaphor and metonymy in comparison and contrast (335-370), Berlin and New York: Mouton de Gruyter. 
De Mendoza Ibáñez, F. J. R., \& Pérez Hernández, P. (2001). Metonymy and the grammar: motivation, constraints and interaction. Language and Communication 21(4), 321-357.

De Mendoza Ibáñez, F. J. R. \& Velasco, O. I. D. (2002). Patterns of conceptual interaction. Patterns of conceptual interaction. In R. Dirven, R. W. Langacker, \& J. R. Taylor (Eds). Metaphor and metonymy in comparison and contrast (489-532) Berlin and New York: Mouton de Gruyter.

Münchau, W. (2019, May 05). Europe must rethink fiscal rules to combat populism. Retrieved from https://www.ft.com/content/6b834848-6daf-11e9-a9a5-351eeaef6d84

Peneva, D. (2019). A corpus-based study on the prepositional phrases in legal vocabulary in English and Bulgarian. KNOWLEDGE - International Journal Scientific Papers, 30(5), 1101-1106.

Todorova, R. (2015) Insights in text linguistics. From theory to practice. Shumen: Konstantin Preslavsky University Press.

Vulliamy, E. (2019, April 28). England and France: A tale of two coastlines. Retrieved from https:/www.theguardian.com/politics/2019/apr/28/england-and-france-a-tale-of-twocoastlines-d-day-anniversary-brexit

Киров, Н. (2019, Мау 02). Българин изчезна в Англия, разследват убийство. Retrieved from https://www.vesti.bg/sviat/bylgarin-izchezna-v-angliia-razsledvat-ubijstvo6094920

Русенова, В. (2019, Мау 03). Нови цени за роуминг в Европа. Retrieved from https:// www.vesti.bg/bulgaria/novi-ceni-za-rouming-v-evropa-6094991

Stoychev, R. (2019, January 28). Американците не харесват външната политика на Тръмп. Retrieved from https://fakti.bg/world/357763-amerikancite-ne-haresvatvanshnata-politika-na-tramp 